\title{
Bacterial biofilms and catheters: A key to under- standing bacterial strategies in catheter-associated urinary tract infection
}

\author{
J CURTIS NICKEL, MD, FRCSC, J WILLIAM COSTERTON, PHD
}

\begin{abstract}
JC NICKEL, JW Costerton. Bacterial biofilms and catheters: A key to understanding bacterial strategies in catheter-associated urinary tract infection. Can J Infect Dis 1992;3(5):261-267. Despite major technological improvements in catheter drainage systems, the indwelling Foley catheter remains the most common cause of nosocomial infection in medical practice. By approaching this common complicated urinary tract infection from the perspective of the biofilm strategy bacteria appear to use to overcome obstacles to produce bacteriuria, one appreciates a new understanding of these infections. An adherent biofilm of bacteria in their secretory products ascends the luminal and external surface of the catheter and drainage system from a contaminated drainage spigot or urethral meatus into the bladder. If the intraluminal route of bacterial ascent is delayed by strict sterile closed drainage or addition of internal modifications to the system, the extraluminal or urethral route assumes greater importance in the development of bacteriuria, but takes significantly longer. Bacterial growth within these thick coherent biofilms confers a large measure of relative resistance to antibiotics even though the individual bacterium remains sensitive, thus accounting for the failure of antibiotic therapy. With disruption of the protective mucous layer of the bladder by mechanical irritation. the bacteria colonizing the catheter can adhere to the bladder's mucosal surface and cause infection. An appreciation of the role of bacterial biofilms in these infections should suggest future directions for research that may ultimately reduce the risk of catheter-associated infection.
\end{abstract}

Key Words: Biofilms, Catheters, Cystits, Nosocomial infections, Urinary tract infections

\section{Biofilms bactériens et cathéters: La clé des stratégies bactériennes dans les infections des voies urinaires associées à la sonde}

RÉSUMÉ: Malgré l'amélioration technologique majeure des dispositifs de drainage par cathéter, le cathéter à demeure de Foley reste la source la plus commune d'infections nosocomiales traitées par les médecins. On acquiert une compréhension nouvelle de ce problème courant compliqué si on l'aborde en tenant compte des stratégies que les bactéries semblent utiliser pour surmonter les obstacles et déclencher une bactériurie. Les bactéries et leurs sécrétions forment un biofilm adhérent qui envahit progressivement la surface intérieure et extérieure du cathéter et de l'appareil de drainage, à partir du robinet de vidange ou du méat urinaire contaminé, pour gagner la vessie. Si la progression intraluminale des bactéries est arrêtée par un circuit de drainage fermé rigoureusement stérile ou par d'autres modifications internes, la voie extérieure ou urétrale assume une plus grande importance dans l'évolution de la bactériurie, qui prend alors considérablement plus longtemps. La prolifération des bactéries à l'intérieur de ces biofilms cohérents épais leur confère un degré élevé de résistance relative aux antibiotiques, même lorsque les bactéries individuelles restent sensibles. Ce phénomène explique l'échec des antibiothérapies. Quand la muqueuse protectrice de la vessie est irritée mécaniquement. les bactéries qui colonisent le cathéter peuvent alors se fixer à la surface de la muqueuse et provoquer des infections. La compréhension du rôle des biofilms bactériens dans ces infections pourrait servir à orienter la recherche et éventuellement réduire les risques d'infection associés au cathétérisme.

Department of Urology. Queen's University, Kingston. Ontario; and Department of Biological Sciences. University of Calgary, Calgary, Alberta

Correspondence and reprints: Dr J Curtis Nickel, Department of Urology. Queen's University, Kingston General Hospital, Kingston, Ontario K7L 2 V7

Received for publication February 20, 1991. Accepted August 1, 1991 
$\mathrm{T}_{\mathrm{a}}$ HE FORMATION OF BACTERIAL BIOFILMS ON SURFACES appears to be a universal bacterial strategy for survival in both nature and disease (1). Recent evidence indicates that bacterial biofilms might also be involved in biomaterial-related bacterial infections (1). This recent improved understanding of the pathogenesis of catheter-associated urinary tract infections may help explain why catheterization remains the most common cause of nosocomial infection in medical practice (2), despite major technological changes in catheter material, design and collecting systems (3). Over the past decade the authors' research group has extensively studied the role of this bacterial mode of growth in the etiology of biomaterial-related urinary tract infection. In this review the data generated by the authors' study of bacterial biofilm growth are summarized and synthesized as they pertain to an understanding of the pathogenesis, prevention and treatment of catheterassociated infections.

\section{THE ASCENDING BACTERIAL BIOFILM}

It is generally accepted that bacteria gain entrance to the bladder from retrograde intraluminal ascent of organisms from contaminated open collection vessels in the early days (4), from the collecting bag or disconnected catheter drainage tube junction since the introduction of the closed urinary drainage system (5-9), and extraluminally from a colonized urethral meatus if strict sterile closed drainage is maintained $(6,7,10,11)$. The retrograde intraluminal spread of organisms was thought to arise from bacteria migrating up the urine column, reflux of infected urine into the bladder, or bacterial transport involving air bubbles (12). However, the addition of vents, flutter valves, air locks and drip chambers to drainage systems did not significantly alter the rates of catheter-associated urinary tract infection $(5,6,8)$. Observations in animal models of the closed catheter drainage system have disclosed that bacteria form thick coherent biofilms adherent to experimentally contaminated drainage spouts extending proximally into the drainage bag and subsequently into the catheter (13,14). Employing a bacteriologically stressed animal model of short term catheterization (fewer than seven days), contamination of the drainage spout or accidental disconnection of the drainage tube resulted in bacteriuria within a short time (32 to $48 \mathrm{~h}$ ). If a strict sterile closed drainage system was maintained and the urethral meatus-catheter junction was inoculated, the extraluminal route would assume greater importance in the development of bacteriuria; however, this pathway was considerably slower (72 to $168 \mathrm{~h}$ ). These findings regarding the relative importance of the intraluminal and extraluminal periurethral routes were confirmed in further animal model studies employing a microbicidal hurdle or barrier in the outlet tube of the drainage bag $(15,16)$. Intraluminal colonization by exogenous bacteria was precluded in the majority of

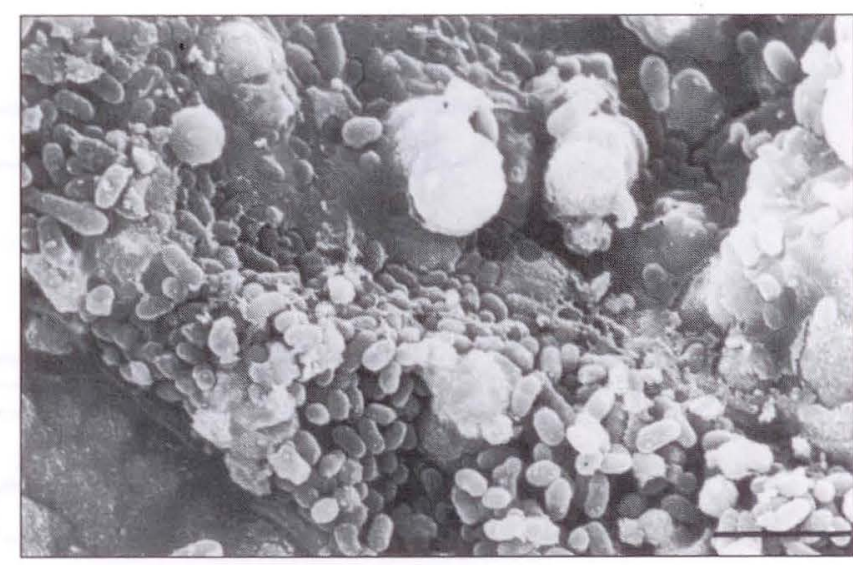

Figure 1) Scanning electron micrograph of the luminal surface of a colonized catheter demonstrating the bacterial cells within coherent biofilms almost completely buried in a condensed slimelike glycocalyx. In some areas the glycocalyx has been lost during preparation, disclosing the bacterial nature of this thick biofilm (lower section) as well as the surface of the catheter (lower left corner). Bar $5 \mu \mathrm{m}$. (Reproduced with permission from reference 19)

animals during the eight day period, and in the $25 \%$ where intraluminal colonization occurred it was significantly delayed (7.2 \pm 1 days). However, downstream colonization of drainage systems, by mixed populations of bacteria that had migrated into the bladder via the extraluminal periurethral route, developed in almost one-half of the animals. Similar bacterial biofilms have been described adherent to urinary drainage bags (17). Foley catheters recovered from patients with catheter associated infections $(18,19)$ and even catheters removed from patients with no bacteriuria (20) (Figure 1). Examination of 10 urinary catheters associated with urinary tract infections by scanning electron microscopy confirmed that the bacteria associated with these infections grew in glycocalyx-enclosed biofilms on the surface of the catheters (19).

The bacterial populations demonstrated a heterogeneity that was not evident from culture results, and it was demonstrated that only a small proportion of the microorganisms - including fungi - identified morphologically by scanning or transmission electron microscopy were recovered by routine culture method.

Employing an in vitro system, it could be clearly demonstrated that the bacteria were ascending the surface of the catheter in a creeping coherent biofilm containing bacterial cells in their secretory products or glycocalyx (21). In the absence of antibiotics it appeared that the ascending bacterial biofilm was moving by two mechanisms: rapidly dividing bacterial cells spreading along the catheter surface within the glycocalyx material of the biofilm, and planktonic or floating bacterial cells within the urine column leapfrogging just ahead of the adherent biofilm, perhaps assisted by the turbulence caused when the urine flow meets the biofilm front. This 'saltatory' bacterial movement may allow some bacteria to establish adherent microcol- 
onies ahead of the ascending biofilm, which expand and coalesce with the main bacterial aggregate into the ascending coherent biofilm (21) (Figure 2).

\section{BLADDER DEFENCES AND THE BACTERIAL BIOFILM}

Planktonic bacteria being released from the biofilm adherent to the Foley catheter can be easily demonstrated in aspirated urine cultures; however, at this point the bacteria are colonizing only the catheter surface and have not yet caused cystitis. The intravesical segment of the Foley catheter eventually becomes covered with a much thicker colonizing adherent bacterial aggregate enclosed within the bacterial slime matrix. This macroscopic bacterial biofilm (Figure 3) can create flow kinetic problems by partially blocking catheter islets and reducing the tubular diameter of the catheter lumen. This biofilm-induced disruption of effective urine flow may increase the volume and perhaps pressure of the residual urine that is always present in catheterized bladders (22). Planktonic bacteria shed from the colonized catheter inhabit this intravesical urine, but the step from asymptomatic bacteriuria to symptomatic catheter-associated cystitis involves actual bacterial adherence to the bladder surface (23).

A thin blanket of mucus or glycosaminoglycan coats the bladder mucosal surface (24) (Figure 4) and appears to inhibit bacterial adherence to the uroepithelium. The indwelling Foley catheter appears to disrupt this bladder mucus or glycosaminoglycan layer (25) and causes mechanical irritation and even erosion of the bladder mucosa, exposing surfaces that allow bacterial adherence. Particular strains of bacteria are more adapted to producing symptomatic catheter-associated cystitis. The ability of strains of Escherichia coli to establish mucosal inflammation seems to correlate with the presence of fimbriae (26), which act as adhesions to uroepithelial cells (27). When sufficient damage is caused to the bladder defence mechanism. and the bacterial inoculum is of critical size and pathogenicity, bacterial adherence to the mucosa or exposed mucosal cell receptors occurs, and the patient develops symptomatic cystitis. Patients who progress from asymptomatic catheter-associated bacteriuria to symptomatic catheter-associated infection complain of bladder irritability, pain and fever secondary to bacterial adherence to, or invasion of, the damaged bladder mucosa, or to subsequent upper tract infection.

\section{ANTIBIOTIC RESISTANCE IN CATHETER-ASSOCIATED BACTERIAL BIOFILMS}

Historically, physicians have used antibiotics both to control and prevent catheter-associated infections with varying and conflicting degrees of success. In an in vitro model it was shown that bacterial growth within thick biofilms adherent to urinary catheter material in an artificial urine milieu conferred a measure of antibiotic resistance on the sessile bacterial cells within the bio-

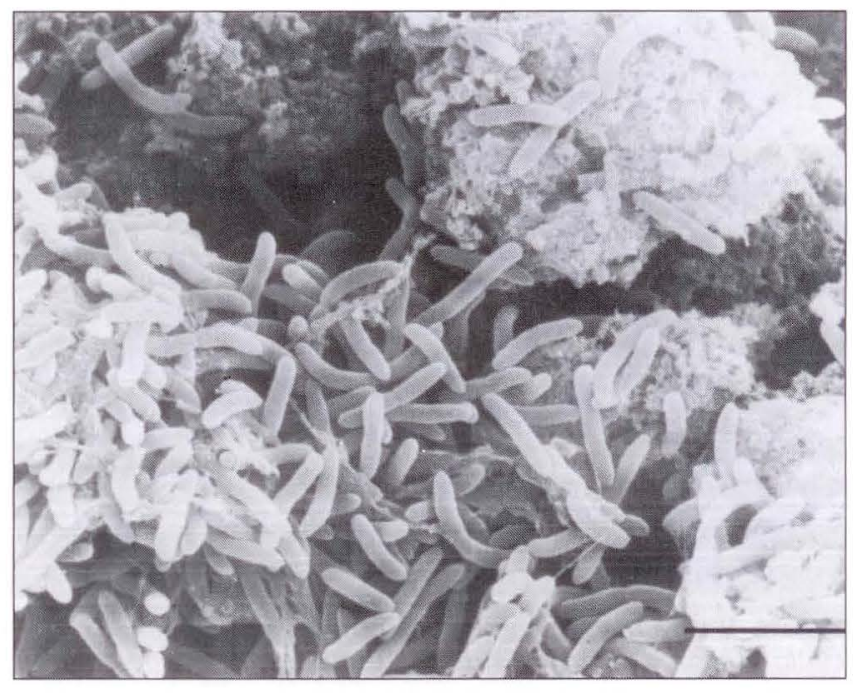

Figure 2) Scanning electron micrograph of experimental bacterial biofilm (lower left) ascending the luminal surface of a Foley catheter (upper right). Bar $5 \mu \mathrm{m}$. (Reproduced with permission from reference 13)

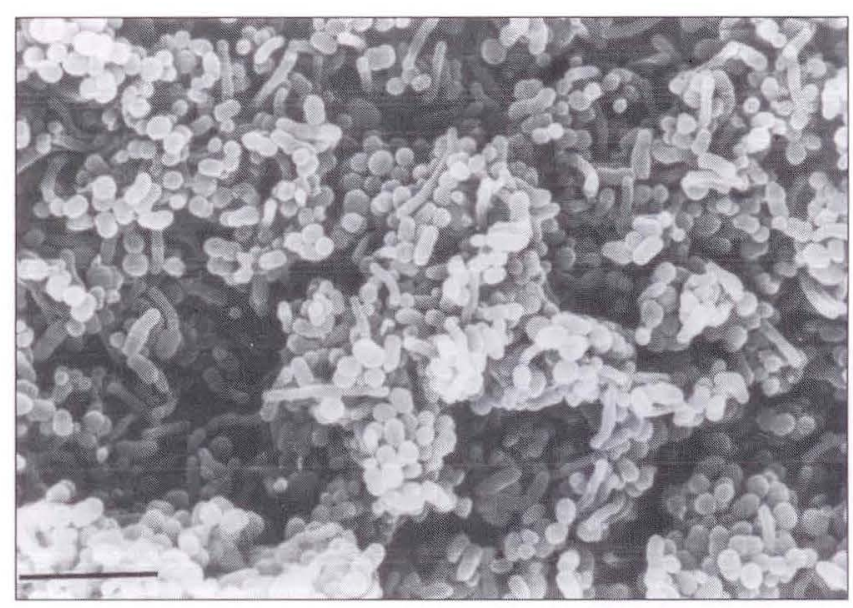

Figure 3) When bacteria reach the intravesical segment of the Foley catheter they form large aggregates that may sometimes be observed macroscopically. This scanning electron micrograph depicts a thick multiorganism biofilm (slime matrix lost during preparation) that has developed on the tip of a Foley catheter in a patient with a Klebsiella species and Enterococcus faecalis bacteriuria. Bar $5 \mu \mathrm{m}$

film (28.29) (Figure 5). In this experiment, disks of urinary catheter material were exposed to the flow of artificial urine containing cells of Pseudomonas aeruginosa forming a thick adherent biofilm composed of these bacteria and their exopolysaccharide products. After this colonization, sterile urine containing tobramycin $1000 \mu \mathrm{g} / \mathrm{mL}$ was flowed past the established biofilm, and a significant proportion of the bacterial cells within the biofilms were found still viable after $12 \mathrm{~h}$ of exposure to this very high concentration of aminoglycoside antibiotic. Planktonic or floating cells taken from the test system just before exposure of the biofilm to the antibiotic were completely killed by $50 \mu \mathrm{g} / \mathrm{mL}$ tobramycin. However, this resistance did not transfer to 


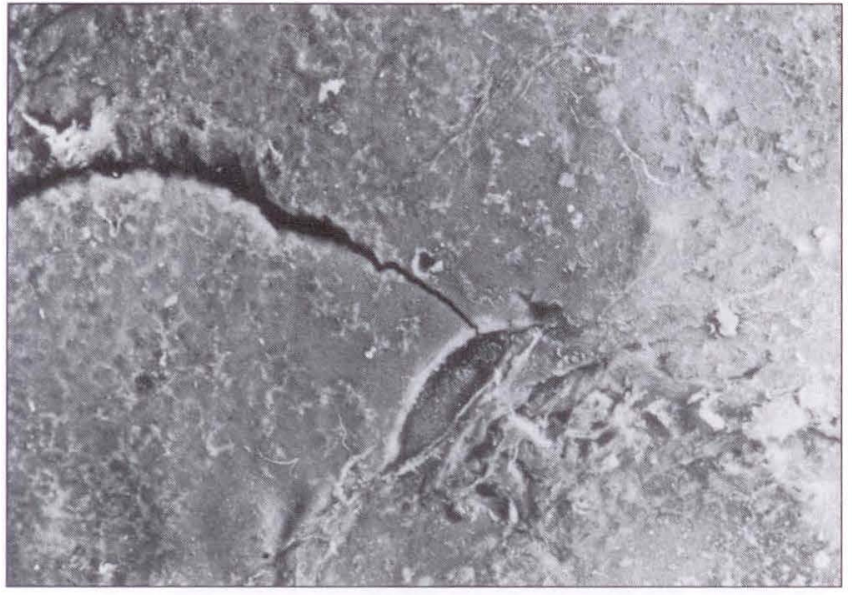

Figure 4) Scanning electron micrograph clearly showing a specially prepared antibody-stabilized mucous layer covering the uroepithelium as a continuous blanket. This mucus or glycosaminoglycan layer acts as a barrier to bacterial adherence. Mechanical or microbial irritation disrupts this protective layer, allowing bacterial adherence and subsequent symptomatic cystitis. The bladder mucosa can be observed through a crescent-shaped defect in the mucus layer. ( $\times 42)$

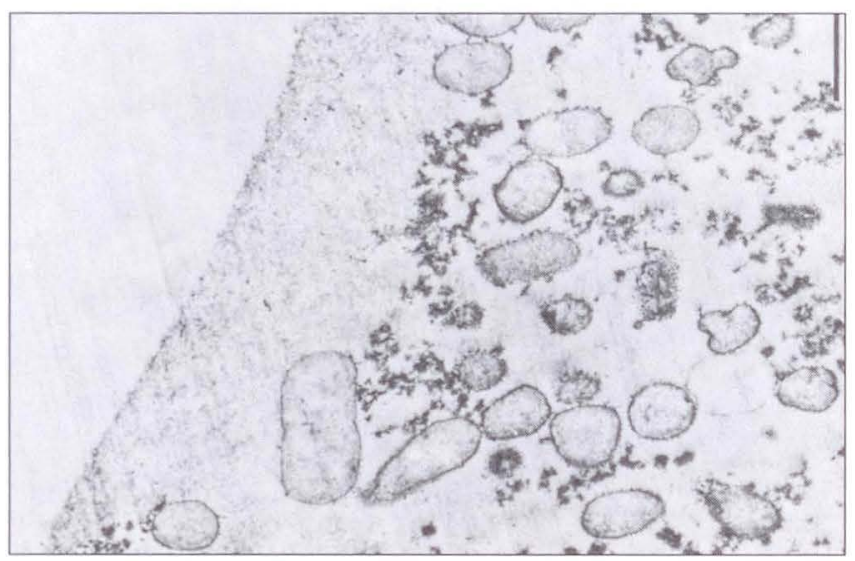

Figure 5) Transmission electron micrograph of a ruthenium red-stained antibody-stabilized preparation of the luminal surface of a pseudomonas biofilm. Antibody stabilization of the surface demonstrates the fibrous anionic matrix binding the bacterial cells together into the biofilm. Through a number of mechanisms this matrix protects the bacteria within the biofilm from antibiotics, even though individual bacteria remain susceptible. Bar 1 um. (Reproduced with permission from reference 28)

these planktonic floating cells in the urine, and 100\% bactericidal activity of high dose tobramycin was observed in this population. The minimal inhibitory concentrations of tobramycin for cells taken from the seeding cultures before colonization of the catheter material and that for dispersed surviving cells recovered directly from the tobramycin-treated biofilm were found to be the same $(0.4 \mu \mathrm{g} / \mathrm{mL})$. This indicates that growth within thick adherent biofilms confers a relative measure of antibiotic resistance on cells of Ps aeruginosa, possibly the result of poor antibiotic penetration of the biofilm matrix (29). Using physiological techniques to study the metabolic activity (radiorespirometric assay) of uropathogenic bacteria growing in biofilms in urine-con- taining systems, the present authors and colleagues have been able to determine that there is a significant reduction in mineralization activity (evolution of carbon dioxide) during antibiotic challenge (30). Respiratory activity ceased almost immediately for planktonic samples, but residual metabolic activity, albeit very much reduced, was detected in sessile catheter-associated bacterial biofilms exposed for more than $18 \mathrm{~h}$ to high antibiotic concentrations. Antibiotic-stressed, catheter-associated bacteria transferred to a post exposure enrichment broth showed an ability to re-establish respiratory activity not observed for the planktonic samples. This decreased metabolic activity of bacteria deep within the biofilm during periods of microbicidal threat may also help to explain the relative resistance of these bacteria to treatment and the observation that catheter-associated bacteria can survive exposure to antibiotics in the clinical setting (31).

When antibiotics are added to an in vitro system assessing bacterial biofilm movement, following a lag phase prolonged for almost $12 \mathrm{~h}$, the biofilm can ascend the catheter surface (21). However, in the experimental setting the biofilm movement was retarded to a rate of about 0.2 to $0.3 \mathrm{~cm} / \mathrm{h}$, compared to bacterial biofilm ascension along the same catheter surface against an identical flow of artificial urine without antibiotics (1 to $2 \mathrm{~cm} / \mathrm{h}$ ). Bacterial biofilm ascent along the external and luminal surface of the catheter appears to be significantly slower in the presence of antibiotics because theoretically antibiotics appear to negate any saltatory planktonic movement of the biofilm. The antibiotic also retards the rapid division of bacteria in the surface areas of the biofilm by either killing them or causing a decrease in metabolic activity; therefore, the biomovement is dependent on the division of bacterial cells deep within the protected matrix of the biofilm (21). The present authors' clinical experience confirms these experimental data that catheter-associated infection remains a problem despite the preventative use of antibiotics (31).

In animal studies, incorporating a microbicidal hurdle or barrier to intraluminal ascending bacterial migration can preclude, for a short time, the intraluminal ascent of the bacterial biofilm; however, the extraluminal or periurethral surface then becomes the predominant route of bacterial entry into the bladder $(15,16)$. Other studies have similarly shown that the addition of antimicrobial solutions to the drainage bag only precludes the intraluminal route of infection $(7,32,33)$. It would therefore be expected that local antimicrobial treatment of the urethral meatus should decrease the rate of catheter-associated infection in patients with a properly maintained closed urinary drainage system, but clinical studies do not confirm this (34).

The use of antibiotics for the prophylaxis of infection has been further examined. In a study designed to 
examine in detail the local effects of different doses of an antibiotic on the establishment of bacterial biofilms in catheter-associated infections, it was discovered that extremely high doses of amdinocillin can destroy and sterilize an Escherichia coli biofilm colonizing the Foley catheter in a rabbit model (35). Unfortunately, the doses required are not clinically practical.

At lower, more clinical doses the bladder wall followed by the bladder urine could be cleared of infecting organisms. Perhaps the natural host defence mechanisms of the bladder mucosa and urine work synergistically with the antibiotic to clear these bacterial populations.

The experimental data suggest that although antibiotics cannot be used to clear bacterial biofilm completely from the surface of the Foley catheter, they do slow down the ascent of the bacterial biofilm and can eradicate, for at least a short time, the bacterial populations adherent to the bladder mucosa that create the symptoms of cystitis. Clinical studies have subsequently also suggested that antibiotics used in short term catheterization may reduce the serious sequelae as sociated with catheter-related infection (36); however, it is obvious that antibiotics would be counterproductive in any form of long term Foley catheterization because of the high possibility of emergence of specific antibiotic-resistant bacterial strains (31). The authors studies in postoperative short term catheterization (two days) (37) suggest that antibiotics and/or expensive bacterial hurdles are not indicated, but rather strict maintenance of a sterile closed system is all that is required. Unfortunately, the definitive data regarding the use of antibiotics in catheterization lasting between two and seven days are not available at this time.

\section{CRYSTALLIZATION WITHIN THE CATHETER-ASSOCIATED BIOFILM}

If the bacterial biofilm adherent to the Foley catheter is inhabited by urease-producing bacteria such as Proteus species, susceptible patients can develop catheter encrustation. This can cause major difficulties in patients requiring long term Foley catheterization. The urease produced by these bacteria hydrolyzes urea to ammonia and raises the $\mathrm{pH}$ of the urine, particularly in the microenvironment of the bacterial biofilm on the catheter surface, allowing calcium, phosphate and struvite crystals to form within the urine and, more importantly, within the biofilm on the catheter surface (38) (Figure 6). The bacterial biofilm matrix entraps the crystals on the catheter surface, which aggregate and coalesce to become macroscopic encrustations. These encrustations are produced in a manner analogous to deposition of struvite calculi within the kidney to create a staghorn calculus. On the catheter, struvite crystals, matrix glycoprotein and uromucoid compounds can and will eventually block the islets and lumen of the catheter $(19,39)$. Irrigation of catheters with acid solu-

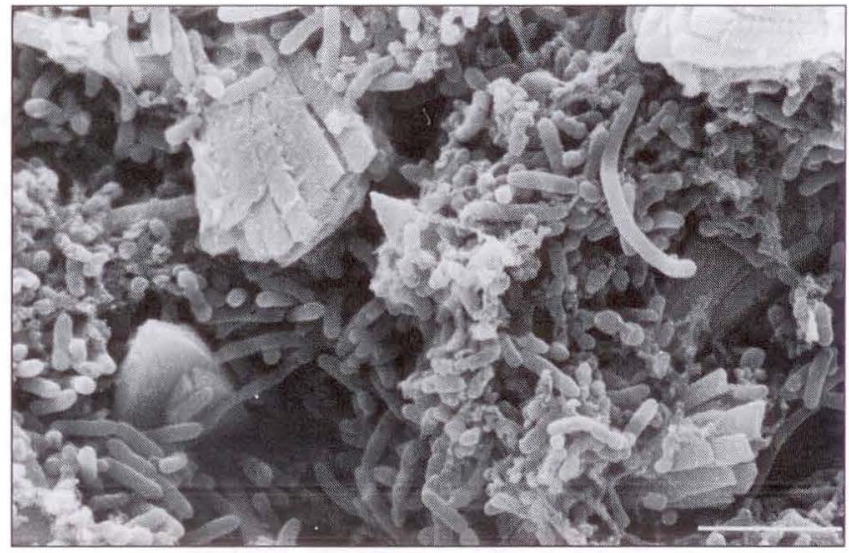

Figure 6) Scanning electron micrograph of the surface of an encrusted catheter shows rod-shaped and coccoid bacterial cells among dehydration condensed residue of the enveloping exopolysaccharoid glycocalyx and uromucoid 'slime'. Discrete crystals are noted within this coherent biofilm. The association of bacteria, slime and crystals leads to eventual obstruction in the catheter. Bar $5 \mu \mathrm{m}$. (Reproduced with permission from reference 38)

tions is sometimes used to prevent and dissolve encrustations, but the actual efficacy and hazards of this procedure perhaps outweigh its benefits. There appears to be a higher risk of bacteremia and sepsis in patients with encrusted catheters secondary to both blockage and the clinical manipulation and irrigation required to clear the blockage. The bladder surface glycosaminoglycan or mucous layer is extremely acid sensitive (24), and irrigation fluids may in fact disrupt further the bladder mucosal surface, allowing for subsequent bacterial adhesion and symptomatic cystitis. There is some evidence, though very limited, that the composition of the catheter and surface characteristics may inhibit the deposition of struvite. There is perhaps less encrustation associated with silicone versus latex catheters (40), but not between silicone and hydrogel-coated latex catheters (41). There also appears to be significant individual patient variation between so-called 'blockers' and 'nonblockers' (42), likely secondary to their inherent urine composition. Some individuals appear to block their catheters repeatedly, while others do not, even when infected with the same species of organism.

\section{FUTURE DIRECTIONS}

It is hoped that further advances in medical technol ogy will allow modification of catheterization procedures, duration and need for catheterization, and provide improvements in the design of catheter urinary drainage systems. Studies have demonstrated that the internal luminal route of catheter-associated infections can be almost completely negated, at least for a short time, by the use of a strictly maintained sterile closed drainage system, with possible addition of a bacterial barrier or hurdle. The design of such a device or mechanism to stop the periurethral route would be very 
helpful. Biomaterial research is an exploding new science, and research must continue with these new materials in respect to mucosal biocompatibility and effectiveness in reducing bacterial biofilm attachment. It is anticipated that new biomaterials will eventually reduce bacterial adherence and biofilm formation and subsequently decrease the rate of catheter-associated infection. New antibiotics being developed may be able to penetrate the bacterial biofilm and may be more effective in this and other prosthesis-related infections. Further studies are required to rationalize the use of

\section{REFERENCES}

1. Costerton JC, Cheng KJ, Geesey GG, et al. Bacterial biofilms in nature and disease. Annu Rev Microbiol 1987:41:435-64.

2. Centers for Disease Control. Nosocomial infection surveillance. MMWR 1984:35: 19SS-86.

3. Platt R. Polk BF, Murdock B, Rosner B. Mortality associated with nosocomial urinary tract infection. N Engl J Med 1982:307:637-42.

4. Kunin CM, McCormack RC. Prevention of catheterinduced urinary tract infections by sterile closed drainage. N Engl J Med 1966;274:1155-61.

5. Thorton GF, Andriole UT. Bacteriuria during indwelling catheter drainage. JAMA 1970;214:339-42.

6. Garibaldi RA, Burke JP, Dickman ML, Smith CB. Factors predisposing to bacteriuria during indwelling urethral catheterization. N Engl J Med 1974:291:215-9.

7. Maizel SM. Schaeffer AJ. Decreased incidence of bacteriuria associated with periodic instillations of hydrogen peroxide into the urethral catheter drainage bag. J Urol 1980;123:84 1-5.

8. Schaeffer AJ. Catheter-associated bacteriuria. Urol Clin North Am 1986:13:735-47.

9. Platt R, Murdock B, Polk J, Rosner B, Reduction of mortality associated with nosocomial urinary tract infection. Lancet 1983;i:893-7.

10. Schaeffer AJ, Chmiel J. Urethral colonization in the pathogenesis of catheter-associated bacteriuria. J Urol 1983; 130: 1096-9

11. Daifuku R. Stamm W. Association of rectal and urethral colonization with urinary tract infection in patients with indwelling catheters. JAMA 1984:252:2028-30.

12. Stamm WE. Guidelines for prevention of catheterassociated urinary tract infections. Ann Intern Med 1975;82:386-90

13. Nickel JC, Grant SK, Costerton JW. Catheter-associated bacteriuria. An experimental study. Urology 1985:26:369-75.

14. Nickel JC. Pathogenesis of catheter-associated bacteriuria. Br J Urol 1988:62:481.

15. Nickel JC, Grant SK. Lam K, Olson ME. Costerton JW. Evaluation in a bacteriologically-stressed animal model of a new closed catheter drainage system incorporating a microbicidal outlet tube. Urology. 1991:38:280-9.

16. Khoury AE, Olson ME, Lam K. Nickel JC. Costerton JW Evaluation of the retrograde contamination guard in a bacteriologically challenged rabbit model. $\mathrm{Br} \mathrm{J}$ Urol 1989:63:384-8.

17. Marrie TJ, Costerton JW. A scanning electron microscopic study of urine droppers and urine collecting systems. Arch Intern Med 1983:143:1135-41.

18. Nickel JC, Gristina AG. Costerton JW. Electron microscopic study of an infected Foley catheter. antibiotics both to prevent and treat catheter-associated infection. New advances in the treatment of cystitis by increasing bladder defence mechanisms - either immunologically or by improving the bladder surface glycosaminoglycan layer - may be helpful in the future in providing better host defence against the bacterial biofilm colonizing the catheter surface. For now the most effective way to reduce the incidence of catheterassociated infection is to avoid indwelling Foley catheterization if at all possible, or at least to reduce the length of time the catheter remains in the bladder.

Can J Surg 1985:28:50-2.

19. Nickel JC, Downey J, Costerton JW. An ultrastructural study of the microbiological colonization of urinary catheters. Urology 1989:34:284-91

20. Ramsay JWA, Garnham AJ, Mulhall AB, et al. Biofilms. bacteria and bladder catheters. Br J Urol 1989:64:395-8.

21. Nickel JC, Downey J, Costerton JW. Movement of Pseudomonas aeruginosa along catheter-surfaces. A mechanism in pathogenesis of catheter-associated infection. Urology 1992;39:93-8

22. Haylen BJ, Fraser MI, MacDonald JH. Assessing the effectiveness of different urinary catheters in emptying the bladder; an application of transvaginal ultrasound. Br J Urol 1989:64:353-6.

23. Daifuku R, Stamm WE. Bacterial adherence to bladder uroepithelial cells in catheter-associated urinary tract infection. N Engl J Med 1986:314:1208-13.

24. Cornish J. Nickel JC, Vanderwee M, Costerton JW. Ultrastructural visualization of human bladder mucus. Urol Res 1990;18:263-6.

25. Vardi Y, Meschulam T, Obedeanj N, Merzback D, Sobel JD. In vivo adherence to Pseudomonas aeruginosa to rat epithelium. Proc Soc Exp Biol Med 1983:172:449-56.

26. Warren JW. Catheter-associated urinary tract infections. Infect Dis Clin North Am 1987:1:823-54.

27. Svanberg-Eden C, Hansson HA. Escherichia coli pili as possible mediators of attachment to human urinary tract epithelial cells. Infect Immun 1978;21:229-37.

28. Nickel JC, Wright JB, Ruseska I, Marrie TJ, Whitfield C, Costerton JW. Antibiotic resistance of Pseudomonas aeruginosa colonizing a urinary catheter in vitro. Eur J Clin Microbiol 1985;4:213-8.

29. Nickel JC, Ruseska I, Wright JB, Costerton JWW. Tobramycin resistance of Pseudomonas aeruginosa cells growing as a biofilm on urinary catheter material. Antimicrob Agents Chemother 1985:27:619-24.

30. Ladd TI, Schmiel D, Nickel JC, Costerton JW. The use of a radio respirometric assay for testing the antibiotic sensitivity of a catheter-associated bacteria. J Urol 1987:138:1451-6.

31. Warren JW, Hoopes JM, Muncie HL, Anthony WC. Ineffectiveness of cephalexin in treatment of cephalexin-resistant bacteriuria in patients with chronic indwelling urethral catheters. J Urol 1983;129:71-3.

32. Garibaldi RA, Burke JP, Britt MR, Miller WA, Smith CB. Meatal colonization and catheter-associated bacteriuria. N Engl J Med 1980:303:316-8.

33. Kunin CM. Genitourinary infections in the patient at risk: Extrinsic risk factors. Am J Med 1984;76:131-9.

34. Burke JP, Jacobson JA, Garibaldi RA, Conti MT, Alling DW. Evaluation of daily meatal care with poly-antibiotic ointment in prevention of urinary catheter-associated bacteriuria. J Urol 1983:129:331-4.

35. Olson ME, Nickel JC, Khoury AE, Morck DW. Cleeland R. 
Costerton JW. Amdinocillin treatment of catheterassociated bacteriuria in rabbits. $J$ Infect Dis 1989:159:1065-72.

36. Vollaard EJ, Clasner HAL, Zambon JV, Joosten HJM, van Griethuysen AJA. Prevention of catheter-associated Gram-negative bacilluria with norfloxacin by selective decontamination of the bowel and high urinary concentration. J Antimicrob Chemother 1989;23:915-22.

37. Nickel JC, Feero P, Costerton JW. Incidence and importance of bacteriuria in post-operative, short-term urinary catheterization. Can J Surg 1988;32:131-2.

38. Nickel JC, Emtage J, Costerton JW. Ultrastructural microbial ecology of infection-induced urinary stones.
J Urol 1985; 133:622-7.

39. Hukins DWL, Hickey DS, Kennedy AP. Catheter encrustation by struvite. Br J Urol 1983:55:304-5.

40. Bruce AW, Sira SS, Clark AF. The problem of catheter encrustation. Can Med Assoc J 1974;111:238-41.

41. Cox AJ, Hukins DWL, Sutton TM. Comparison of in vitro encrustations on silicone and hydrogel-coated latex catheters. Br J Urol 1988;61:156-61.

42. Kunin CM, Chin GF, Chambers S. Formation of encrustations on indwelling urinary catheters in the elderly: A comparison of different types of catheter materials in "blockers" and "nonblockers". J Urol 1987;138:131-2. 


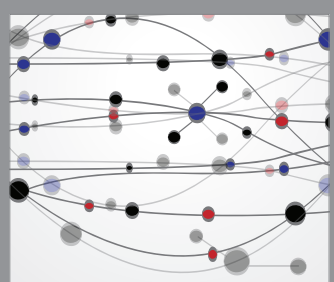

The Scientific World Journal
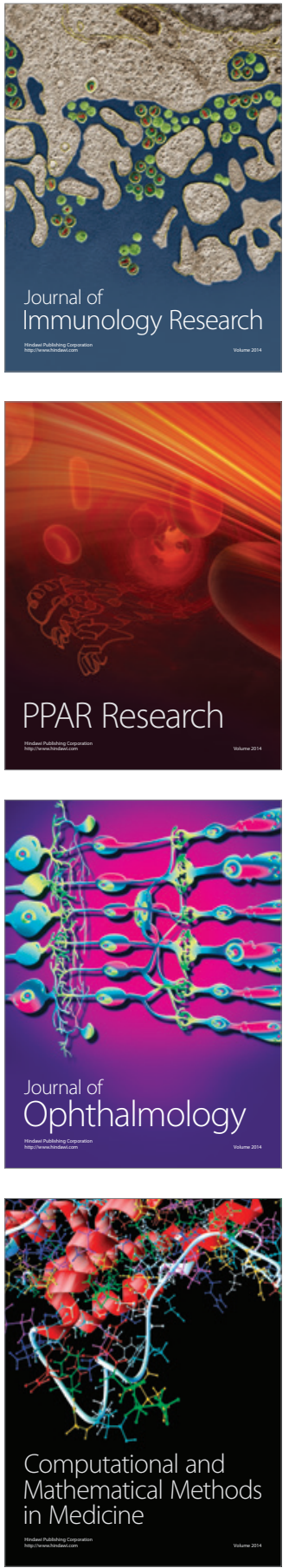

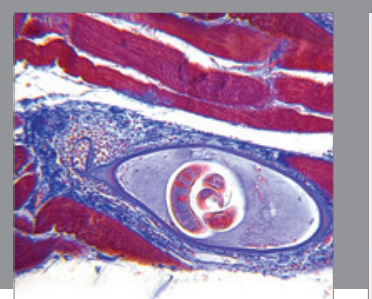

Gastroenterology Research and Practice

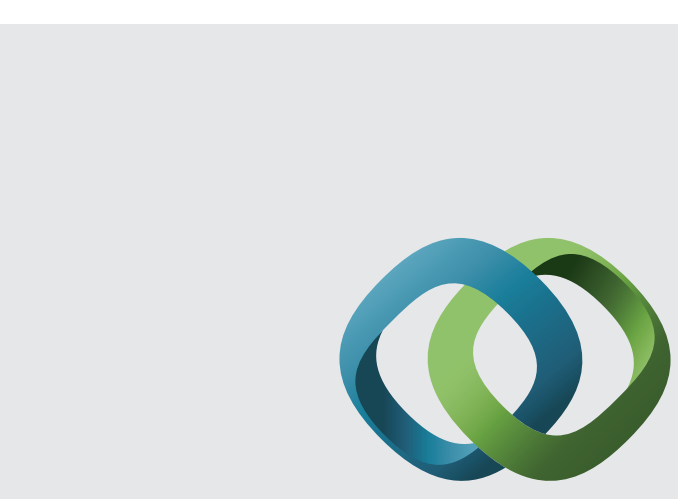

\section{Hindawi}

Submit your manuscripts at

http://www.hindawi.com
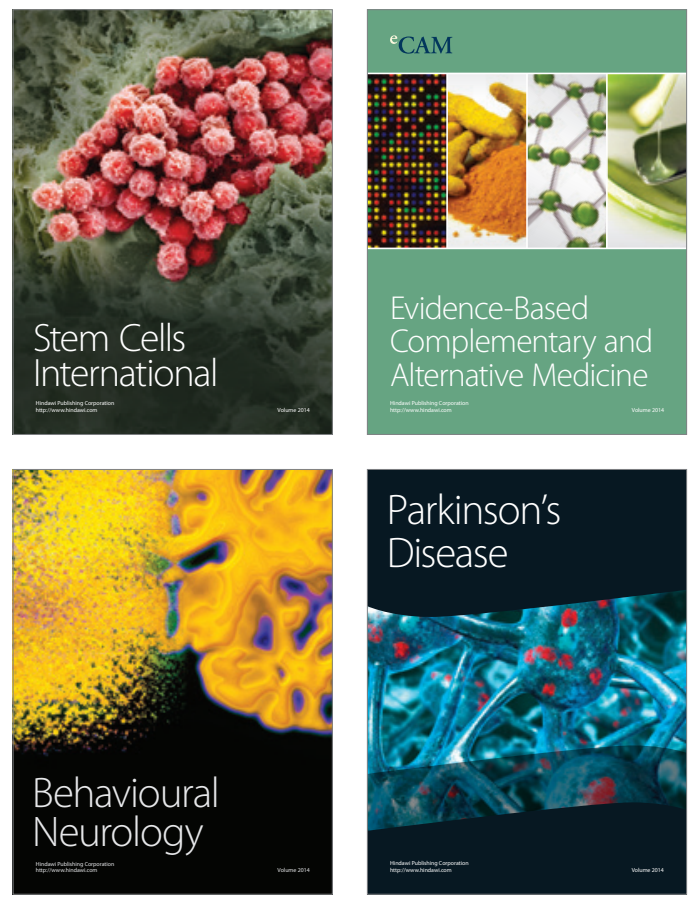
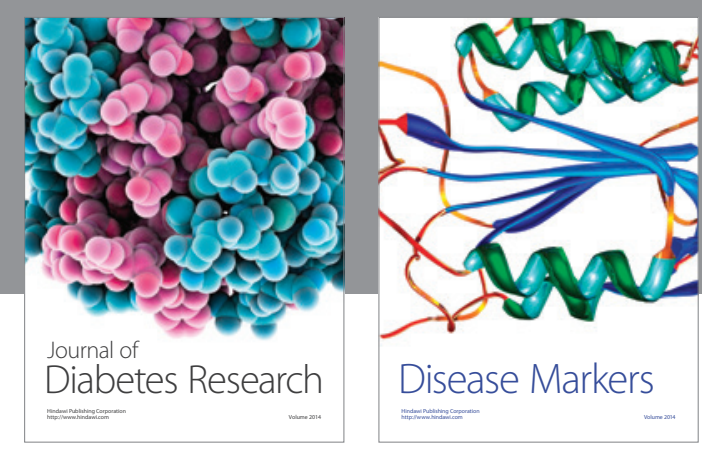

Disease Markers
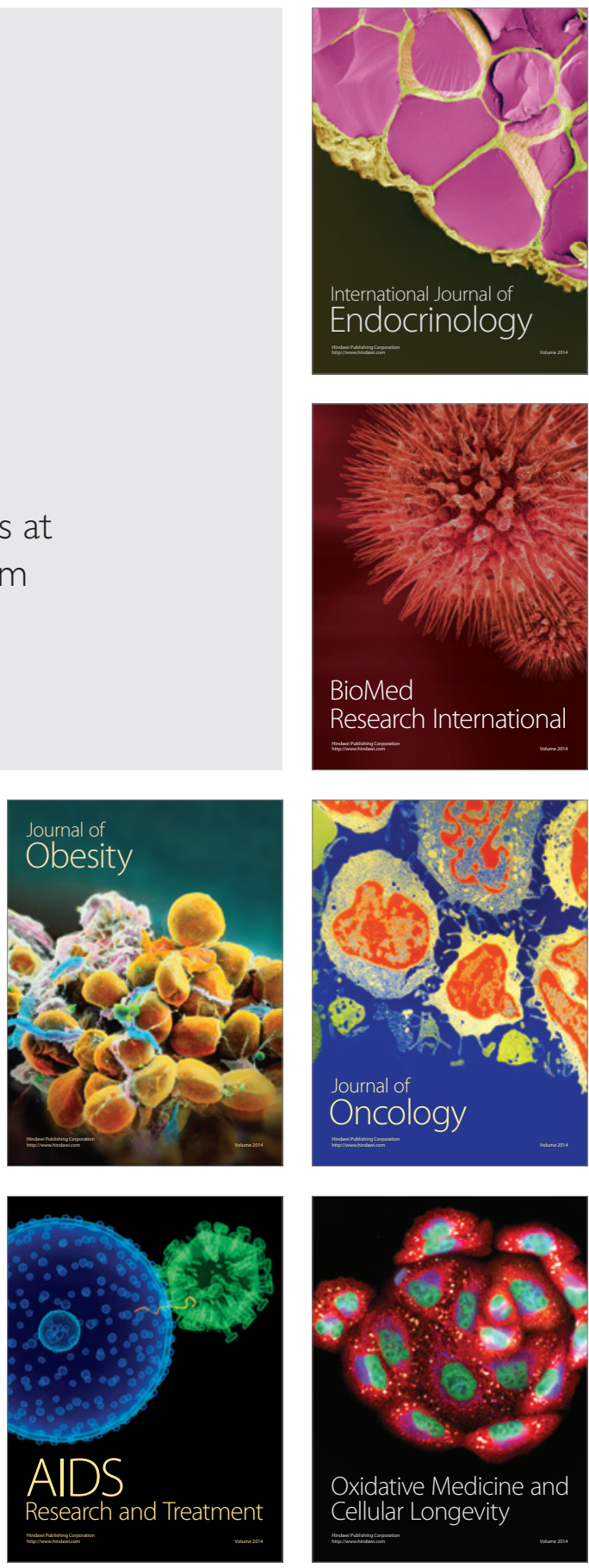